\title{
ROLA WIZUALIZACJI DANYCH W KOMUNIKACJI NAUKOWEJ. NOWE SPOSOBY WIZUALIZACJI DANYCH
}

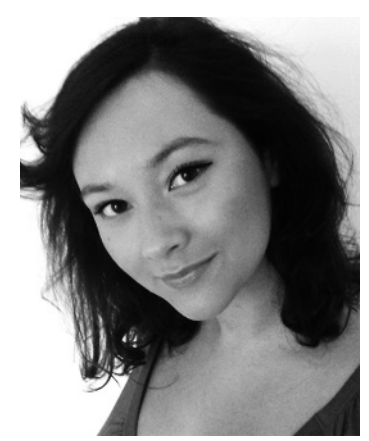

Magdalena Wójcik, dr, adiunkt w Instytucie Informacji Naukowej i Bibliotekoznawstwa Uniwersytetu Jagiellońskiego. Jej zainteresowania badawcze obejmują problematykę nowych form komunikacji w Internecie, w tym szczególnie mediów społecznościowych i ich związków z działalnością instytucji książki. Najważniejsze publikacje to: Web 2.0 w działalności usługowej instytucji ksią̇ki (Kraków, 2013), Rozszerzona rzeczywistość - potencjał badawczy z perspektywy bibliologii i informatologii, Przegląd Biblioteczny 2014, R. 82, z. 4, s. 565-581 oraz The Use of Web 2.0 Services by Urban Public Libraries in Poland: Changes over the Years 2011-2013, Libri 2015, Vol. 65, Issue 2, pp. 91-103.

SŁOWA KLUCZOWE: Badania naukowe. Druk 3D. Hologramy. Wirtualna rzeczywistość. Rozszerzona rzeczywistość. Wizualizacja danych.

ABSTRAKT: Teza/cel: Przedmiot artykułu stanowi zagadnienie wizualizacji danych w nauce. Celem artykułu jest dokonanie systematycznego przeglądu nowych sposobów i narzędzi wizualizacji danych naukowych. Metoda: Zastosowano metodę analizy i krytyki piśmiennictwa. Dokonano przeglądu piśmiennictwa z lat 2010-2015 biorąc pod uwagę publikacje w języku polskim i angielskim. Zebrane piśmiennictwo poddano kategoryzacji, celem wyodrębnienia kluczowych trendów w wizualizacji danych naukowych. Analizy piśmiennictwa dokonano w oparciu o wyszukiwanie w bazach Biblioteki Narodowej, katalogu WorldCat oraz zagranicznych bazach danych, które przeszukano za pomocą narzędzia Google Scholar. Uzupełniająco dokonano także przeglądu zasobów sieciowych, w tym szczególnie blogów i portali branżowych. Wyniki: Do najczęściej omawianych sposobów wizualizacji danych za pomocą nowych narzędzi należą: infografiki, postery, hologramy, druk 3D oraz wizualizacje tworzone w środowisku wirtualnej i rozszerzonej rzeczywistości. Wnioski: Ważnym problemem wymagającym 
rozwiązania jest przetwarzanie dynamicznych, rozległych i nieustrukturyzowanych zbiorów danych, które wymykają się tradycyjnym analizom. Potrzebne jest tworzenie wizualizacji danych w taki sposób, by były one dla użytkowników angażujące, interaktywne i sprzyjały immersji.

\section{WSTĘP}

Wizualizacja danych odgrywa w nauce istotną rolę jako element sprzyjający zrozumieniu i zapamiętywaniu wyników badań naukowych (Paradowski, 2011). Współcześnie, w kontekście zagadnień związanych z rozwojem idei otwartego dostępu do nauki (ang. Open Access) oraz na fali popularności koncepcji Nauki 2.0 (Szczęsny, 2013), korzystanie z dobrych narzędzi służących obrazowaniu danych staje się elementem propagowania idei otwartości i przejrzystości badań naukowych. Jasne i czytelne prezentowanie danych, w taki sposób, by ich sens był zrozumiały dla szerokiej publiczności, jest postrzegane jako element popularyzacji wyników badań naukowych. Przydatne może się zatem okazać poddanie krytycznej analizie współczesnych metod, technik i narzędzi służących wizualizacji danych pod kątem ich przydatności do obrazowania danych naukowych.

\section{PRZEDMIOT I CEL}

Przedmiot badań stanowi zagadnienie wizualizacji danych w nauce. Celem jest dokonanie systematycznego przeglądu nowych sposobów i narzędzi wizualizacji danych. Wśród celów szczegółowych można wymienić:

- ustalenie stanu badań nad narzędziami wizualizacji danych,

- określenie, w oparciu o analizę literatury przedmiotu, dominujących trendów w wizualizacji danych,

- dokonanie przeglądu nowych narzędzi i metod obrazowania wyników badań naukowych,

- omówienie perspektyw rozwoju wizualizacji danych oraz dokonanie oceny potencjału wybranych narzędzi dla wizualizacji wyników badań bibliologicznych i informatologicznych.

\section{KLUCZOWE TERMINY}

Wizualizacja danych polega, najogólniej, na graficznym przedstawieniu danych w taki sposób, by ich sens był bardziej czytelny i łatwiej przyswajalny dla obiorcy (Paradowski, 2011). Wpisuje się to w szerszy kontekst komunikacji wizualnej, postrzeganej na gruncie nauk o zarządzaniu czy kulturoznawstwa, jako skuteczna metoda wywierania wpływu na odbiorcę i oddziaływania na jego sferę emocjonalną, wykorzystywana między innymi w przekazach marketingowych (Arnheim, 2013; Ciesielska, 2013). Idea wizualizacji danych opiera się więc na przekonaniu, że materiał wizual- 
ny może po pierwsze: łatwiej zwrócić uwagę odbiorcy, po drugie: silniej na niego oddziaływać poprzez swoją graficzną formę, po trzecie: sprzyjać utrwaleniu przekazu w świadomości odbiorcy.

\section{METODA}

Zastosowano metodę analizy i krytyki piśmiennictwa. Dokonano systematycznego przeglądu piśmiennictwa z lat 2010-2015 biorąc pod uwagę publikacje $\mathrm{w}$ języku polskim i angielskim. Zebrane piśmiennictwo poddano kategoryzacji, celem wyodrębnienia kluczowych trendów w wizualizacji danych naukowych. Analizy piśmiennictwa dokonano w oparciu o wyszukiwanie w bazach Biblioteki Narodowej ${ }^{1}$, katalogu WorldCat oraz w zagranicznych bazach danych, które przeszukano za pomocą narzędzia Google Scholar. Uzupełniająco dokonano także przeglądu zasobów sieciowych, w tym szczególnie blogów i portali branżowych (np. Lustro Biblioteki, Bibliosfera itp.).

\section{STAN BADAŃ}

Przeprowadzona analiza stanu badań pokazuje, że problematyka wizualizacji danych była tematem stosunkowo często poruszanym w literaturze przedmiotu. Najczęściej rozważano problemy takie jak:

- wpływ wizualizacji danych na procesy decyzyjne w biznesie i w nauce (Mahoney, 2013; Duch, 2015),

- prezentacja danych w postaci infografik (Smiciklas, 2012; Krum, 2013; Dick, 2014),

- prezentacja danych za pomocą narzędzi wirtualnej i rozszerzonej rzeczywistości (Marks, Estevez \& Connor, 2014),

- wizualizacja tzw. wielkich danych (Keim, Qu \& Ma, 2013; Teras \& Raghunathan, 2015),

- wizualizacja danych z wykorzystaniem technologii druku 3D (Segerman, 2013; McMenamin et al., 2014),

- wykorzystanie hologramów w wizualizacji (Almeida et al., 2013; Hobson, Reid \& Wilton, 2013)

- wykorzystanie storytellingu w wizualizacji danych (Lee, Kazi \& Smith, 2013; Kosara \& Mackinlay, 2013).

Przeważały artykuły anglojęzyczne, tworzone głównie na gruncie dziedzin innych niż bibliologia i informatologia (nauk o kulturze, informatyki, nauk o zarządzaniu i innych). Spośród polskich publikacji bibliotekoznawczych na szczególną uwagę zasługuje dorobek V. Osińskiej (Osińska, 2010; 2012), w tym najnowsza książka WIZualizacja INFOrmacji: studium informatologiczne (Osińska, 2016).

\footnotetext{
${ }_{1}^{1}$ „Przewodnik Bibliograficzny” i „Polska Bibliografia Bibliologiczna”
} 
Problematyka wizualizacji danych w nauce była w ostatnich latach poruszana nie tylko w piśmiennictwie, ale także na konferencjach naukowych i branżowych. Przykładem może być konferencja „Wizualizacja wiedzy. Od Biblia Pauperum do hipertekstu” (Konferencja..., 2010), seminarium "Wizualizacja danych i wyników badań naukowych" (XV Seminarium..., 2014), międzynarodowa konferencja „Data Visualisation in Science Communication” (BSA Science..., 2014) oraz konferencja "Wizualizacja dla nauki" (Konferencja..., 2015). Problematyka ta znalazła się również w obszarze zainteresowań kluczowych organizacji i stowarzyszeń bibliotekarskich na świecie, w tym Association of College and Research Libraries i American Library Association (ACRL, 2015; ALA, 2015), była także szeroko poruszana w blogosferze (Newman, 2015; Zoss, 2016). Pokazuje to potrzebę dyskusji nad zagadnieniem wizualizacji danych na forum badaczy i praktyków.

\section{WIZUALIZACJA W KOMUNIKACJI NAUKOWEJ}

Wizualizacja danych w naukach humanistycznych i społecznych odbywa się według ustalonego schematu. W artykułach naukowych publikowanych drukiem graficzne przedstawienia danych występują najczęściej w formach takich jak: tabela, wykres, rysunek czy zdjęcie, często reprodukowanych w stosunkowo niskiej jakości i najczęściej w wersji czarno-białej. W publikacjach elektronicznych wizualizacja może być, choć wciąż rzadko jest, wzbogacana o elementy interaktywne i multimedialne. W trakcie wykładów i prezentacji ustnych materiałem wzbogacającym przekaz jest najczęściej prezentacja multimedialna w programie PowerPoint, choć od jakiegoś czasu często także w formie nielinearnej opartej o program Prezi lub podobne (Jarosz, 2011). Ciekawą i wciąż stosunkowo nowa jeśli chodzi o polskie konferencje, formą prezencji danych jest poster (Rowe \& Ilic, 2015), jednak jego idea nie zawsze jest jasna dla prelegentów, co owocuje prostym przepisywaniem kluczowych fragmentów artykułu do postera i wzbogacaniem całości kilkoma fotografiami lub wykresami. Można założyć, że w przypadku prezentowania prostych danych statystycznych tego rodzaju wizualizacje sprawdzają się i są wystarczające do zrozumienia przekazu, choć nie zawsze stanowią atrakcję dla odbiorcy. W przypadku bardziej złożonych zestawów danych lub konieczności przedstawienia bardziej skomplikowanych zagadnień pojawia się jednak potrzeba zmiany i wyjścia poza przyjęty kanon. Pojawiają się zatem postulaty bazujące na idei tzw. humanistyki cyfrowej, w których zachęca się autorów do podjęcia wysiłku w kierunku usprawnienia przepływu danych w nauce za pomocą nowych narzędzi informacyjno-komunikacyjnych (Radomski \& Bomba, 2013). Opracowanie skutecznych metod nowoczesnej wizualizacji danych wydaje się w tym kontekście szczególnie istotne. 


\section{NOWE NARZĘDZIA WIZUALIZACJI DANYCH}

Jednym z najczęściej używanych sposobów wizualizacji danych, popularnym szczególnie w środowisku sieciowym, jest tworzenie infografik. Idea opiera się na syntetycznym i atrakcyjnym wizualnie przedstawieniu danych $\mathrm{w}$ formie graficznej, która przypomina nieco poster naukowy. Sam termin może być rozumiany szeroko, jako każda - jak nazwa wskazuje - grafika przekazująca informację - lub wąsko, nawiązując do współczesnych sieciowych odmian infografik, które charakteryzują się wysokim poziomem projektowania graficznego, oryginalnością i dużą atrakcyjnością wizualną (Mauldin, 2015). Do cech charakterystycznych można zaliczyć m.in.: wertykalną organizację informacji, używanie dużych, wyrazistych czcionek oraz unikanie długich opisów zjawisk na rzecz operowania nagłówkami i grafiką (Lankow, Ritchie \& Crooks, 2012). Do zalet infografik można zaliczyć bez wątpienia ich syntetyczny charakter i atrakcyjną szatę graficzną. Uniwersalny charakter infografik pozwala na prezentowanie w tej formie różnych typów danych, głównie statystyk, koncepcji i modeli, co może znaleźć zastosowanie $\mathrm{w}$ wielu dyscyplinach naukowych, $\mathrm{w}$ tym również w bibliologii i informatologii. Tworzenie tego rodzaju wizualizacji wymaga jednak podstawowych umiejętności z zakresu projektowania graficznego i umiejętności przekazywania informacji w zwartej formie. Pomocą mogą okazać się dostępne w sieci narzędzia, w tym: XMind, Tableau Public, Easelly czy Canva.

Storytelling jest definiowany jako technika prezentacji oparta o przekazywanie informacji w formie opowieści. Charakterystyczną cechą tej formy jest wyraźna struktura i rytm prezentacji, zmierzający do założonego przez twórcę finału. Celem jest wzbudzenie u odbiorcy zainteresowania, emocji i chęci podjęcia określonego działania (Lee, Kazi \& Smith, 2013). Współcześnie technika storytellingu jest często wzbogacana o elementy wizualizacji, rysunki, zdjęcia, szkice, które wspierają prezentowaną historię i oddziałują na wyobraźnię odbiorcy tworząc tzw. data storytelling (Knaflic, 2015). Zdaniem niektórych autorów tego rodzaju techniki mogą być z powodzeniem używane nawet do wizualizowania $z$ w. wielkich danych, a więc dużych i nieuporządkowanych zbiorów informacji (Madhavan et al., 2012). Do zalet storytellingu należy bez wątpienia angażujący charakter tego rodzaju obrazowania danych, do wad można jednak zaliczyć ryzyko zmanipulowania przekazu poprzez nadmierne odwoływanie się do sfery emocjonalnej odbiorcy, co szczególnie w przypadku wizualizacji danych naukowych jest dużym mankamentem.

Wizualizacja danych może się również odbywać w wirtualnych, całkowicie sztucznych, wygenerowanych cyfrowo środowiskach (Marks, Estevez \& Connor, 2014) lub też w warunkach łączących obraz świata rzeczywistego z tym wygenerowanym komputerowo (Schall et al., 2009). Narzędzia takie 
jak np. Oculus Rift dają możliwość prezentacji danych w realistycznym, trójwymiarowym środowisku wirtualnym, w sposób który całkowicie odcina bodźce zewnętrzne i pozwala skupić się jedynie na oferowanym przekazie. Zawieszony obecnie, choć mający potencjał - Google Glass czy urządzenia mobilne wyposażone w specjalne aplikacje dają z kolei możliwość nakładania w czasie rzeczywistym dodatkowej warstwy informacyjnej na realne miejsca i obiekty, tworząc możliwość prezentacji danych w sposób łączący elementy realne i wirtualne. Środowiska wirtualnej i rozszerzonej rzeczywistości otwierają nowe i nie do końca jeszcze eksplorowane możliwości przedstawiania danych w sposób angażujący, interaktywny i oparty nie tylko o ogląd danych, ale umożliwiający odbiorcy zanurzenie się w interaktywnym świecie informacji. Wydaje się, że tego rodzaju technologie są przyszłością wizualizacji. Konieczne jest jednak opanowanie zarówno przez nadawcę, jak i odbiorcę przekazu kompetencji związanych z odbiorem danych prezentowanych $w$ takiej formie, zarówno tych związanych ze sferą technicznej obsługi nowych narzędzi, jak i tych należących do sfery information/media literacy.

Hologramy są metodą wizualizacji danych opartą o prezentowanie realistycznie wyglądających, trójwymiarowych obiektów 3D, dającą ogromne możliwości, stosowaną najczęściej w kontekście prezentacji biznesowych oraz w naukach ścisłych i przyrodniczych (Blanche et al., 2010; Mirza et al., 2013). Do zalet hologramów można zaliczyć ich atrakcyjną formę wizualna, trójwymiarowy charakter i uniwersalność. W postaci holograficznej można przedstawiać obraz osób, miejsc, przedmiotów, modeli czy wykresów. Interesujące przykłady wdrożeń holograficznej wizualizacji danych można zaobserwować w niektórych instytucjach kultury, zwłaszcza muzeach (np. Dubaï Museum), które wykorzystują je do nadbudowywania nad istniejącymi fragmentami budynków czy przedmiotów holograficznej wersji ich oryginalnego wyglądu. Łatwo sobie wyobrazić analogiczne zastosowanie hologramów w badaniach z zakresu bibliologii, w tym szczególnie w badaniach rękopisów i starodruków. Holograficzna wizualizacja danych, podobnie jak w przypadku technik opartych o wirtualną czy rozszerzoną rzeczywistość, wymaga użycia specjalistycznego oprogramowania i sprzętu oraz konieczności operowania zestawem odpowiednich kompetencji technicznych, informacyjnych i medialnych.

Druk 3D, dający możliwość łatwego tworzenia w warunkach domowych trójwymiarowych modeli i prototypów, jest coraz częściej wykorzystywany jako metoda wizualizacji danych, szczególnie w naukach ścisłych i medycznych. Możliwość wydruku dokładnych, trójwymiarowych pomocy naukowych jest szeroko wykorzystywana przez studentów medycyny do nauki anatomii (McMenamin et al., 2014), ale także przez inżynierów czy projektantów do tworzenia prototypów opracowywanych rozwiązań (Segerman, 2012), czy kuratorów muzeów do tworzenia kopii dzieł sztuki 
(Smithsonian..., online). Do zalet druku 3D należy bez wątpienia możliwość nadania modelom i symulacjom realnej, namacalnej, trójwymiarowej postaci, co może ułatwiać zrozumienie danych, szczególnie tych o charakterze abstrakcyjnym lub trudnym do opisowego przedstawienia.

PRZETWARZANIE BIG DATA - NOWE WYZWANIA DLA WIZUALIZACJI DANYCH

Istotnym zagadnieniem ostatnich lat jest wizualizacja tzw. wielkich danych (ang. big data), definiowanych jako duże, nieuporządkowane, zmienne zbiory danych pochodzące $\mathrm{z}$ różnych źródeł, które są trudne w przetwarzaniu ze względu na swój złożony charakter (Mayer-Schönberger, 2014). Analiza wielkich danych jest konieczna ze względu na ich dużą przydatność zarówno w nauce, jak i w biznesie. Wielkie dane mogą ujawnić nowe tendencje i powiązania między elementami, które w innych okolicznościach nie byłyby widoczne. Przyczynia się to do tworzenia nowej wiedzy i umożliwia podejmowanie trafnych decyzji (McAfee et al., 2012; Provost \& Fawcett, 2013). Opracowanie i wizualizacja wielkich danych nie może się jednak odbywać za pomocą standardowych narzędzi, konieczne jest stosowanie specjalnego oprogramowania. Na problemy związane z wizualizacją danych zwracają uwagę Mikołaj Pindelski i Rafał Mrówka. Zdaniem autorów próby przedstawiania wielkich danych metodami tradycyjnymi, np. w tabelach, powoduja, że stają się one nieczytelne i tracą swój wyjątkowy charakter. Konieczne jest rozwijanie techniki graficznego przedstawiania przestrzeni trójwymiarowych, na przykład za pomocą oprogramowania OpenGL, które pozwala na kreatywne i przestrzenne łączenie obrazów i danych liczbowych (Pindelski \& Mrówka, 2014).

Wizualizacja wielkich danych jest ciekawym polem działania dla bibliologów i informatologów, zarówno w kontekście naukowym, jak i praktycznym. Opracowanie, w porozumieniu z informatykami skutecznych metod wizualizacji wielkich danych, mogłoby przynieść korzyści na poziomie teoretycznym i stosowanym oraz przyczynić się do popularyzacji dyscypliny.

\section{WNIOSKI}

Do najczęściej omawianych sposobów wizualizacji danych za pomocą nowych narzędzi należą: infografiki, postery, hologramy, druk 3D oraz wizualizacje tworzone w środowisku wirtualnej i rozszerzonej rzeczywistości. Ważnym problemem jest również przetwarzanie dynamicznych, rozległych i nieustrukturyzowanych zbiorów danych, które wymykają się tradycyjnym analizom. Coraz większy nacisk kładziony jest również na interaktywność, namacalność i immersyjność przedstawiania danych. 
Analiza literatury przedmiotu pokazuje, że do najbardziej obiecujących narzędzi, jeśli chodzi o obrazowanie danych, należeć będą przede wszystkim wizualizacje tworzone w oparciu o technologię wirtualnej i rozszerzonej rzeczywistości, hologramy oraz druk 3D. Wskazuje to na potrzebę tworzenia wizualizacji interaktywnych, multimedialnych i wielowymiarowych. Odbiorca powinien móc nie tylko zapoznać się z danymi, ale także wejść z nimi $\mathrm{w}$ interakcję, dotknąć ich wirtualnej lub fizycznej reprezentacji i zanurzyć się w środowisku informacyjnym. Stawia to przed nauką nowe wyzwania.

Pozostaje rozważyć, w jaki sposób opisane narzędzia i sposoby wizualizacji danych mogą wpłynąć na obrazowanie wyników badań bibliologicznych i informatologicznych. Wydaje się, w oparciu o analizę literatury przedmiotu z zakresu innych nauk humanistycznych i społecznych, że tendencje polegające, $z$ jednej strony, na przedstawianiu informacji w sposób skondensowany i atrakcyjny wizualnie, z drugiej, bazujące na interaktywności, multimedialności i immersyjności mogą znaleźć zastosowanie także w nauce o książce i nauce o informacji. Szczególnie interesujące, z punktu widzenia badań bibliologicznych osadzonych w nurcie historycznym wydaje się wykorzystanie technik holograficznych oraz rozszerzonej rzeczywistości do tworzenia wizualizacji oryginalnego wyglądu dokumentów bez fizycznej ingerencji w badany obiekt. W badaniach zachowań informacyjnych użytkowników szczególnie pomocna może się okazać technologia wirtualnej rzeczy wistości, która pomogłaby prezentować dane w środowisku naśladującym kontekst badania. Na użytek wizualizacji dla celów dydaktycznych, szczególnie użyteczna mogłaby być technologia druku 3D, pozwalająca na tworzenie namacalnych, fizycznych reprezentacji abstrakcyjnych modeli i projektów oraz storytelling, który prezentuje dane w sposób pozwalający utrzymać uwagę i zaangażowanie odbiorców.

Podsumowując warto zaznaczyć, że wykorzystanie technik wizualizacji ma za zadanie uwypuklić znaczenie samych danych i pomóc w ich zrozumieniu, nie może zatem dominować przekazu, ani odwracać uwagi od zasadniczych treści. Z tej perspektywy najważniejsze wydaje się zatem zachowanie umiaru i korzystanie $z$ bardziej zaawansowanych technik wizualizacji wtedy, gdy jest to rzeczywiście konieczne i uzasadnione.

\section{BIBLIOGRAFIA}

Almeida, Trevor P., et al. (2015). Visualisation of high temperature magnetisation states in magnetite grains using off-axis electron holography. Journal of Physics: Conference Series [online], vol. 644. no. 1. IOP Publishing, 2015 [dostęp: 27.01.2016]. Dostępny w WWW: <http://iopscience.iop.org/article/10.1088/1742-6596/644/1/012027/pdf>.

American Library Asociation (2015). Seeing is Believing: Understanding Data Visualization for Library Research [online], [dostęp: 25.01.2016]. Dostępny w WWW: <http://www.ala.org/offices/cors/seeing-believing-understanding-data-visualization-library-research-webinar>. 
Arnheim, Rudolf (2013). Myślenie wzrokowe. Gdańsk : Wydaw. Słowo/Obraz Terytoria.

Association of College and Research Libraries (2015). Data Visualization: Tools, Techniques, and Practice [online], [dostęp: 25.01.2016]. Dostępny w WWW: <http://www.ala.org/ acrl/datavisualizationpreconference>.

Blanche, Pierre-Alexandre, et al. (2010). Holographic three-dimensional telepresence using large-area photorefractive polymer. Nature, vol. 468.7320 (2010), pp. 80-83.

BSA Science Communication Conference "Data Visualisation in Science Communication" [online], [dostęp: 16.02.2016]. Dostępny w WWW: <http://scienceogram.org/talk/>.

Ciesielska, Małgorzata (2013). Komunikacja wizualna w działaniu. W: Komunikacje w rozmowie. Pod red. M. Wszołek. Wrocław; Kraków: Wydaw. Libron - Filip Lohner, s. 103-121.

Dick, Murray (2014). Interactive infographics and news values. Digital Journalism [online], vol. 2.4 (2014), pp. 490-506 [dostęp: 20.01.2016]. Dostępny w WWW: <http://dspace. brunel.ac.uk/bitstream/2438/9791/2/Fulltext.pdf>.

Duch, Włodzisław (2015). Visualization for science policy makers [online], [dostęp: 19.01.2016]. Dostępny w WWW: <http://lectorium.edu.pl/wizualizacja-dla-nauki/prezentacje/>.

Hobson, Peter R.; Reid, Ivan. D.; Wilton, Jayne B. (2013). Visualizing Breath using Digital Holography. Journal of Physics: Conference Series [online], vol. 415, no. 1. IOP Publishing [dostęp: 10.02.2016]. Dostępny w WWW: <http://iopscience.iop.org/article/10.1088/1742-6596/415/1/012078/pdf>.

Jarosz, Bożena (2011). Prezi versus PowerPoint [online], [dostęp: 26.02.2016]. Dostępny w WWW: <http://www.ktime.up.krakow.pl/symp2011/referaty2011/jarosz.pdf>.

Keim, Daniel; Qu, Huamin; Ma, Kwan-Liu (2013). Big-data visualization. Computer Graphics and Applications, IEEE [online], vol. 33.4 (2013), pp. 20-21 [dostęp: 25.01.2016]. Dostępny w WWW: <http://ieeexplore.ieee.org/stamp/stamp.jsp?arnumber=6562707>.

Knaflic, ColeNussbaumer(2015). Storytelling with data: a datavisualization guidefor business professionals [online]. Hoboken, New Jersey: Wiley [dostęp: 05.01.2016]. Dostępny w WWW: $<$ https://books.google.pl/books?id=rRSRCgAAQBAJ\&printsec=frontcover\&dq=data + storytelling\&hl $=$ pl\&sa $=X \&$ redir_esc $=y \# v=$ onepage $\& \mathrm{q}=$ data $\% 20$ storytelling \& $\mathrm{f}=$ false $>$.

Konferencja „Wizualizacja wiedzy. Od Biblia Pauperum do hipertekstu”, Warszawa, 9-11.12.2010 [online], [dostęp: 25.01.2016]. Dostępny w WWW: <http://www.kopernik.org.pl/news/n/konferencja-wizualizacja-wiedzy-od-biblia-pauperum-do-hipertekstu/>.

Konferencja „Wizualizacja dla nauki", Warszawa, 18.09.2015 [online], [dostęp: 28.01.2016]. Dostępny w WWW: <http://lectorium.edu.pl/wizualizacja-dla-nauki/>.

Kosara, Robert; Mackinlay, Jock (2013). Storytelling: The next step for visualization. Computer [online], no. 5 (2013), pp. 44-50 [dostęp: 25.01.2016]. Dostępny w WWW: <http:// citeseerx.ist.psu.edu/viewdoc/download?doi=10.1.1.303.1294\&rep=rep1\&type=pdf $>$.

Krum, Randy (2013). Cool infographics: effective communication with data visualization and design [online], John Wiley \& Sons [dostęp: 20.01.2016]. Dostępny w WWW: <https:// books.google.pl/books?hl=pl\&lr=\&id=mea2AQAAQBAJ\&oi=fnd\&pg=PR13\&dq=infographic+data+visualisation \&ots=4pMhxeDull\&sig=hs_q9_GxCDT6Gym-DzW7LeIHaIg\&redir_esc $=\mathrm{y} \# \mathrm{v}=$ onepage\&q\&f=false $>$.

Lankow, Jason; Ritchie, Josh; Crooks, Ross (2012). Infographics: the power of visual storytelling [online], Hoboken, New Jersey: John Wiley \& Sons, Inc. [dostęp: 14.01.2016]. Dostępny w WWW: <https://books.google.pl/books?id=x7tLPkYQBxoC\&pg=PT65\&dq=infographic\&hl=pl\&sa=X\&ved=0ahUKEwipgb_twfnKAhUDNhoKHWklCQMQ6AEIPDA$\mathrm{E} \# \mathrm{v}=$ onepage $\& \mathrm{q}=$ infographic $\& \mathrm{f}=$ false $>$. 
Lee, Bongshin; Kazi, Rubaiat Habib; Smith, Graeme (2013). SketchStory: Telling more engaging stories with data through freeform sketching. Visualization and Computer Graphics, IEEE Transactions [online], no 19.12 (2013), pp. 2416-2425 [dostęp: 25.01.2016]. Dostępny w WWW: <http://research-srv.microsoft.com/en-us/um/redmond/groups/cue/publications/TVCG2013-SketchStory.pdf>.

Madhavan, Jayant, et al. (2012). Big Data Storytelling Through Interactive Maps. IEEE Data Eng. Bull [online], vol. 35.2 (2012), pp. 46-54 [dostęp: 13.01.2016]. Dostępny w WWW: <http://citeseerx.ist.psu.edu/viewdoc/download?doi=10.1.1.300.3419\&rep=rep1\&type=pdf\#page=48>.

Mahoney, Jamie (2013). Data visualisation and statistical analysis within the decision making process [online], [dostęp: 15.01.2016]. Dostępny w WWW: <http://eprints.lincoln. ac.uk/7011/1/Data_Visualisation_and_Statistical_Analysis_Final_Submission.pdf $>$.

Marks, Stefan; Estevez, Javier E.; Connor, Andy M. (2014). Towards the Holodeck: fully immersive virtual reality visualisation of scientific and engineering data. In: Proceedings of the 29th International Conference on Image and Vision Computing New Zealand ed. Michael Cree. New York: ACM [online], [dostęp: 15.01.2016]. Dostępny w WWW: <https://aut. researchgateway.ac.nz/bitstream/handle/10292/8215/holodeck_ivcnz2014_preprint. pdf?sequence $=14 \&$ is Allowed $=y>$.

Mauldin, Sarah (2015). Data Visualizations and Infographics [online]. Lanham: Rowman \& Littlefield [dostęp: 15.01.2016]. Dostępny w WWW: <https://books.google.pl/ books?id=190vCgAAQBAJ\&printsec=frontcover\&dq=infographic\&hl=pl\&sa=X\&ved= 0ahUKEwipgb_twfnKAhUDNhoKHWklCQMQ6AEILDAC\#v=onepage\&q=infographic\&f=false $>$.

Mayer-Schönberger, Victor (2014). Big data: rewolucja, która zmieni nasze myślenie, pracę i życie. Warszawa: MT Biznes.

McAfee, Andrew, et al. (2012). "Big data." The management revolution, Harvard Bus Rev., no. 90.10 (2012), pp. 61-67.

McMenamin, Paul G., et al. (2014). The production of anatomical teaching resources using three-dimensional (3D) printing technology. Anatomical sciences education [online], no. 7.6 (2014) pp. 479-486 [dostęp: 18.01.2016]. Dostępny w WWW: <http://www.allthings3d.net/podcast/images/McMenaminPaper.pdf>.

Mirza, Kamran, et al. (2013). Holography in clinical anatomy education: a systematic review. Medical Posters [online], 1.4 (2013) [dostęp: 16.02.2016]. Dostępny w WWW: $<$ http://medicalposters.co.uk/index.php/mp/article/viewFile/53/32>

Newman, Tom (2015). Library Data Visualization [online], [dostęp: 19.01.2016]. Dostępny w WWW: <http://librarydatavisual.blogspot.com/>.

Osińska, Veslava (2010). Wizualizacja i wyszukiwanie dokumentów. Warszawa: Wydaw. SBP.

Osinska, Veslava (2012). Wizualizacja paradygmatów badawczych. W: Zagadnienia naukoznawstwa, 3 (193), pp. 205-220.

Osińska, Veslava (2016). WIZualizacja INFOrmacji. Studium informatologiczne. Toruń: Wydaw. Naukowe Uniwersytetu Mikołaja Kopernika.

Paradowski, Michał (2011). Wizualizacja danych - dużo więcej, niż prezentacja. W: Wizualizacja wiedzy: od Biblia Pauperum do hipertekstu. Pod red. Macieja Kluzy. [online]. Lublin: Portal WiE [dostęp: 15.01.2016]. Dostępny w WWW: <http://publikacje.ils.uw.edu.pl/ publication/view/polski-wizualizacja-danych-duzo-wiecej-niz-prezentacja/>.

XV seminarium w cyklu Badania naukowe "Wizualizacja danych i wyników badań naukowych", Warszawa, 13.11.2014 [online], [dostęp: 25.01.2016]. Dostępny w WWW: <http://www. cpi.com.pl/imprezy/2014/wdwn/index.php>. 
Pindelski, Mikołaj; Mrówka, Rafał (2014). Wizualizacje Big Data w identyfikacji problemów zarządzania. W: Prace naukowe Uniwersytetu Ekonomicznego we Wroctawiu red. nauk. Ewa Głuszek i Grzegorz Bełz, nr 363. Wrocław: Wydaw. UEW s. 18-28.

Provost, Foster; Fawcett, Tom (2013). Data science and its relationship to big data and data-driven decision making. Big Data [online], vol. 1.1 (2013), pp. 51-59 [dostęp: 15.01.2016]. Dostępny w WWW: <http://online.liebertpub.com/doi/full/10.1089/big.2013.1508?utm_ content=bufferf7c04\&utm_medium=social\&utm_source=twitter.com\&utm_campaign=buffer $>$.

Radomski, Andrzej; Bomba, Radosław (2013). Zwrot cyfrowy w humanistyce: internet, nowe media, kultura 2.0. [online]. Lublin: E-Naukowiec [dostęp: 26.02.2016]. Dostępny w WWW: $<$ http://e-naukowiec.eu/wp-content/uploads/2013/05/Zwrot_cyfrowy_w_humanistyce.pdf>.

Rowe, Nicholas; Ilic, Dragan (2015). Rethinking poster presentations at large-scale scientific meetings-is it time for the format to evolve? FEBS Journal [online], vol. 282.19, pp. 3661-3668.

Segerman, Henry (2012). 3D printing for mathematical visualisation. The Mathematical Intelligencer [online], vol. 34, issue 4, pp. 56-62 [dostęp: 15.01.2016]. Dostępny w WWW: $<\mathrm{http}$ ///math.okstate.edu/people/segerman/papers/3d_printed_visualisation.pdf $>$.

Schall, Gerhard, et al. (2009). Handheld augmented reality for underground infrastructure visualization. Personal and ubiquitous computing [online], vol. 13.4 (2009), pp. 281-291.

Smiciklas, Mark (2012). The power of infographics: Using pictures to communicate and connect with your audiences. Indianapolis: Que Publishing.

Smithsonian X 3D [online], [dostęp: 10.01.2016]. Dostępny w WWW: <http://3d.si.edu/about>.

Szczęsny, Paweł (2013). Otwarta nauka, czyli dobre praktyki uczonych [online]. Toruń: Stowarzyszenie Ebib 62 [dostęp: 15.02.2016]. Dostępny w WWW: <https://www.fosteropenscience.eu/sites/default/files/pdf/783.pdf $>$.

Teras, Marko; Raghunathan, Shriram (2015). Big data visualization in immersive virtual reality environments: embodied phenomenological perspectives to interaction. ICTACT Journal on Soft Computing [online], vol. 5.4, pp. 1009-1015 [dostęp: 15.01.2016]. Dostępny w WWW: <http://www.researchgate.net/profile/Marko_Teraes/publication/280640341_ Big_Data_Visualisation_in_Immersive_Virtual_Reality_Environments_Embodied_ Phenomenological_Perspectives_to_Interaction/links/55c082bf08aec0e5f4478674.pdf $>$.

Zoss, Angela (2016). Data and Vizualization Services Blog [online], [dostęp: 16.01.2016]. Dostępny w WWW: <http://blogs.library.duke.edu/data/>.

Artykuł w wersji poprawionej wptyną do Redakcji 1 grudnia 2016 r. 
Magdalena Wójcik

Institute of Information and Library Studies

Jagiellonian University

e-mail: magda.wojcik@uj.edu.pl

\title{
THE ROLE OF DATA VISUALIZATION IN SCHOLARLY COMMUNICATION. NEW METHODS OF DATA VISUALIZATION
}

KEYWORDS: Research. 3D printing. Holograms. Virtual reality. Augmented reality. Data visualization.

\begin{abstract}
Thesis/Objective - The author focuses on data visualization in science and analyzes new methods and tools used for scientific data visualization. Research methods New trends in data visualization were identified through the analysis of respective literature in Polish and English published from 2010 to 2015. The literature was searched for in the databases of National Library of Poland, WorldCat international union catalog and foreign databases available through Google Scholar. The search was complemented with the analysis of web resources, in particular blogs and portals related to the field discussed. Results - The most often used and discussed new data visualization methods are: infographics, posters, holograms, 3D printing and visualizations built in the environment of virtual and augmented reality. Conclusions - Processing dynamic, large and unstructured pools of data which escape traditional analysis is a significant issue requiring some solutions. Data visualization needs to be user-engaging, interactive and supporting user immersion.
\end{abstract}

